Article 32

When a coastal State exercises the rights referred to in Articles 30 and 31 it shal promptly notify the flag State of the suspected violation and of the respective measures which have been taken.

Article 33

The rights conferred on the coastal State by Articles 27 to 32 may be exercised only by officials or agents having the authority to establish that a violation has been committed.

Article 34

When taking measures against a foreign vessel pursuant to Articles 27 to 32 , the State in question will immediately inform the consular or diplomatic representative of the flag State of the vessel against which the measures were taken.

\section{Article 35}

A vessel may be detained only by virtue of a court order of the State having jurisdiction. The vessel must be immediately released if the person responsible pays the fine imposed.

If as a result of an arrest the coastal State decides that it is necessary to detain the vessel, it must be taken to a safe and convenient place of anchorage.

\section{Article 36}

The coastal State may exercise the powers provided for in Article 35 only to the extent that there is no excessive danger to the vessel in question and that no unreasonable risks are created for navigation or the marine environment.

\section{Article 37}

The coastal State must provide for recourse in its courts in respect of loss or damage resulting from the inspection, the enquiry or application of measures taken pursuant to Articles 27 to 36 where they exceed those which were reasonably necessary in view of existing information.
Article 38

In the exercise of its rights and duties under this Chapter, a State shall not discriminate in form or in fact against foreign vessels.

\section{Article 39}

Nothing in Chapters six and seven shall affect the legal regime of straits used for international navigation.

\section{Article 40}

States shall have the right to enforce laws and regulations adopted in accordance with the provisions of this Convention for the protection and preservation of the marine environment from atmospheric sources of marine pollution.

\section{CHAPTER EIGHT: RESPONSIBILITY AND LIABILITY}

Article 41

1. States have the responsibility to ensure that activities under their jurisdiction or control do not cause damage to areas under the jurisdiction of other States or to the marine environment of other States and shall, in accordance with principles of international law be liable to other States for such damage.

2. States have the responsibility to ensure that activities under their jurisdiction or control do not cause damage to the marine environment beyond areas where States exercise sovereign rights in accordance with this Convention.

3. When necessary, States shall co-operate in the development of international law relating to the protection and preservation of the marine environment in establishing inter alia criteria and procedures for the determination of liability, the assessment of damage, the payment of compensation and the settlement of related disputes.

\section{CHAPTER NINE: SOVEREIGN IMMUNITY}

\section{Article 42}

The provisions of Chapters Six and Seven shall not apply to any warship, naval auxiliary or other vessel owned or operated by a State and used, for the time being, only on govern ment noncommercial service. However, each State shall ensure by the adoption of appropriate measures not impairing the operations or operational capabilities of such vessels or other craft owned or operated by it, that such vessels or other craft act in a manner consistent, so far as is reasonable and practicable, with Chapters Six and Sevem.

\section{CHAPTER TEN: OTHER CONVENTIONS ON PRESERVATION OF THE MARINE ENVIRONMENT}

\section{Article 43}

1. The provisions of this Convention shall be without prejudice to the specific obligations assumed by States under special conventions and agreements concluded previously which relate to the prevention of pollution of the marine environment nor to agreements which may be concluded in furtherance of the general principles set forth in this Convention.

2. Specific obligations assumed by States under special conventions, with respect to the protection and preservation of the marine environment should be applied in a manner consistent with the general principles and objectives of this Convention.

\section{CHAPTER ELEVEN: SETTLEMENT OF DISPUTES}

\section{Article 44}

Any dispute with respect to the interpretation or application of the provisions of this Convention with respect to the preservation of the marine environment shall be resolved by the dispute settlement procedures contained in Chapter of this Convention.

\title{
BOOK NOTES
}

Private Remedies for Transfrontier Environmental Disturbances. By Stephen C. McCaffrey. International Union for Conservation of Nature and Natural Resources: Morges, Switzerland. 1975. Pp. 157. \$6.00. The eighth number in the IUCN Environmental Policy and Law Paper series is a scholarly study of legal problems to be overcome and alternatives to be chosen in seeking private remedies for transnational pollution. The author sees the private lawsuit for injunction or recovery of damages as frequently being preferable to efforts at the intergovernmental level to solve international environmental problems. In this way responsibility for pollutionrelated injuries may be determined through the relatively straightforward

Environmental Policy and Law, 1 (1975) processes of private delictual law as opposed to the murky and often unenforceable rules of public international law. As a third alternative, the author suggests that states open their administrative decisionmaking processes to interested foreign parties on the same basis as they are open to their own citizens, so as to facilitate the prevention of transfrontier environmental disturbances before injury occurs.

Professor McCaffrey's detailed analysis makes clear that the way to a private law verdict in a case of transfrontier pollution is not an easy one. However, his thorough discussion of the problems of choosing a forum, of jurisdiction, of choice of law, of remedies, and of enforcing a judgment once obtained should be of practical value to an attorney seeking to develop litigation strategies in this field. Of course, the author's conclusions should not be taken as Gospel. Thus, for example, he states that "generally speaking, jurisdiction could properly be asserted over a foreign defendant on the basis of the harmful effects in the forum state of his emissions", a conclusion contradicted by a recent Dutch court decision in the Rhine River pollution case discussed elsewhere in this issue.

In addition to discussing the application of domestic law to transfrontier pollution cases, McCaffrey also considers the various international conventions relevant to such cases. $\mathrm{He}$ proceeds from this analysis to propose very useful elements of a future transfrontier pollution agreement. In general, this book represents a significant contribution to scholarly discussion and practical solution of the legal problems associated with transfrontier environmental disturbances. 
The International Law of Pollution.

By James Barros and Douglas M. Johnston. The Free Press: New York. 1974. Pp. xvii, 476. This work is a collection of research and teaching materials relevant to the international law of pollution prevention and control. Except for a brief introduction and occasional notes, the volume is composed entirely of excerpts from official and semi-official documents, mostly international agreements and decisions of national and international tribunals. The International Law of Pollution is not designed for easy reading, but it is more a reference work than a book to be read from cover to cover. As such, it is a useful compilation of essential materials in a most important field of law.

Control of Pollution Act 1974. By J. F. Garner. Butterworths: London. 1975. Pp. xi, 157. $£ 5.85$. This book is a practitioner's guide to the United Kingdom's Control of Pollution Act 1974, an omnibus environmental protection measure concerned primarily with solid waste disposal, control of water pollution, and noise abatement. In addition to a brief general introduction and introductions to each major part of the Act, the book presents each section of the Act together with annotations and other explanatory notes. The volume would be something of a puzzle to non-British readers, but is a useful tool for the practicing attorney.

\section{A Clear View: Guide to Industrial}

Pollution Control. By James Cannon. Inform Inc.: New York. 1975. Pp. 235. $\$ 4.00$. This is not only an interesting but a useful book. It is designed to be used by the concerned citizen who wishes to determine for himself and his community whether the local industrial plant is operating in compliance with laws designed to protect the environment. The emphasis on utility is clear from the author's references to other publications - including publishers' addresses and purchase prices - - as well as from the how-to-do-it approach of the book as a whole -- with chapters on "understanding the problem", "gathering factory data", "evaluating the data", and "having an impact".

The author is not satisfied with demanding rights of citizen participation nor pleading for the citizenry to make use of the rights it has. He is concerned with transforming the citizen's abstract 152 legal right into a concrete social force, by telling him how to find out what legal requirements for pollution control are, how to measure a particular industrial plant's compliance with those requirements, and what to do with his conclusions.

This is a straightforward and refreshing book. Although it particularly concerns the laws of the United States, where provisions for citizen participation are fairly advanced, it provides a good example for other industrial countries as well. The reader is not likely to find any earthshaking insights in its pages, but he may discover that upon reading $A$ Clear View he can no longer rely upon the convenient excuse: "I'd like to do something about pollution, but I just don't know how! "

\section{Environmental Policy and Administra-} tion. By Daniel H. Henning. American Elsevier Publishing Co.: New York, 1974. Pp. xvii, 205. \$14.50, Dfl. 34.50 This work is a courageous attempt by one man to cover a very broad topic. As would be expected, this has the advantages and disadvantages common to many such single-authored texts.

The advantages include a coherency of style and treatment. Generally handling his topics evenly, Henning gives the intermediate amount of detail suitable for making this work useful in classroom instruction or as a primer for people interested in getting an even, light background in environmental policy and administration.

His approach and scope also have the traditional disadvantages. It is doubtful that anyone could be familiar with the wide scope of subjects which Henning attempts to explore. As expressed in the Forward by Lynton Caldwell, no such single authored work exists for environmental policy and administration and it is doubtful that such a definitive text is possible, given the complexity of the subject and its still increasing range. Do not read Henning to get the last word on each area of. environmental policy and administration - the book is far too short to attempt such an ambitious goal (176 pages of text) and it is doubtful if any man has such a fund of knowledge. Also, given the scope of his topic, Henning has of necessity relied upon resource material within a limited time span (generally until approximately the end of 1972) making his book a bit dated. A further weakness of the book is Henning's reliance upon external sources. Sometimes the reader is subjected to a string of citations and quotations, to which the author has added only the minimum of transitional links.

In summary, Henning has given us a book with a wide scope, suitable, if rather expensive, as a general primer or for classroom use. Like many such books, however, this one also has the drawbacks of an occasional superfluity of footnotes and quotations, dated references and tantalizingly over-general discussions.

Subvention oder Sonderabschreibung?: Special Depreciation Allowances or Subsidies?: Amortissements exceptionnels ou subventions? By Hermann Soell Volume A 33 in the series, Beiträge zür Umweltgestaltung. Erich Schmidt Verlag: West Berlin, 1975. Pp. 68. This is a trilingual edition, in German, English and French, of a brief report by Professor Soell of the University of Regensburg concerning the utility of subsidies and special depreciation allowances as instruments for promoting pollution control and other environmental interests. Professor Soell confronts three important issues: (1) the apparent conflict between governmental support for pollution control investments and the principle that the polluter should pay;(2) the relative utility of subsidies and tax write-offs as means of governmental assistance in the environmental sphere; and (3) the question whether a proposed provision for special depreciation allowances in the tax law of the Federal Republic of Germany would violate Article 92 of the EEC Treaty, which prohibits the granting of competition-distorting tax concessions by member states.

In the course of an interesting discussion, the author argues that the polluter-pays-principle should not be so rigidly interpreted as to prohibit economically realistic measures for temporary relief. He sees assistance through the tax system as more effective and ultimately less expensive than through subsidies, and concludes that such measures would not be in conflict with the EEC Treaty. His analysis is concise but well-documented, and is a useful contribution to this unglamorous but extremely important sector of environmental law.

Also included is a resolution adopted in February 1975 by the European Council on Environmental Law endorsing the conclusions reached by Professor Soell. 